\title{
Adherence to ventilator-associated pneumonia prevention measures in intensive care
}

Adesão às medidas de prevenção de pneumonia associada à ventilação mecânica em terapia intensiva Adhesión a las medidas para prevenir la neumonía asociada con la ventilación mecánica en cuidados intensivos

Fabiola Alves Gomes ${ }^{1}$, Denise Von Dolinger de Brito Röder², Thúlio Marquez Cunha', Geraldo Magela Cardoso Filho², Clesnan MendesRodrigues ${ }^{1}$, Guilherme Silva Mendonça ${ }^{4}$, Eliana Borges Silva Pereira ${ }^{4}$

How to cite this article:

Gomes FA, Röder DVDB, Cunha TM, Cardoso Filho GM, Mendes-Rodrigues C, Mendonça GS, et al. Adherence to ventilator-associated pneumonia prevention measures in intensive care. Rev Pre Infec e Saúde [Internet]. 2020;6:9165. Available from: https://revistas.ufpi.br/index.php/nupcis/article/view/9165 DOI: https://doi.org/10.26694/repis.v6i0.9165

1 Federal University of Uberlândia, School of Medicine, Nursing Department, Uberlândia, Minas Gerais, Brazil.

2 Federal University of Uberlândia, Graduate Program in Health Sciences, Uberlândia, Minas Gerais, Brazil.

3 University Center of Triângulo,

Physiotherapy Department, Uberlândia, Minas Gerais, Brazil.

${ }^{4}$ Federal University of Uberlândia, Hospital de Clínicas de Uberlândia, Uberlândia, Minas Gerais, Brazil.

\begin{abstract}
Introduction: Ventilator-Associated Pneumonia (VAP) is a frequent infection in patients admitted to intensive care units. The occurrence of VAP prolongs hospital stay and increases health care costs. The objective of this study is to assess adherence of health professionals to a VAP prevention package of interventions (Bundle). Outline: Retrospective, documentary study performed in an intensive care unit of a university hospital. The sample consisted of patients hospitalized in the period from January to June 2014, who met the inclusion criteria. The data collection was carried out through examination of medical records. Results: Increase in hospital stay of patients with VAP and low adherence to Bundle items were verified. Proper cuff pressure and oral hygiene with standardized antiseptic were the items with lower adherence. Implications: The adherence to some Bundle VAP prevention measures was not different between groups of patients (with or without VAP) and showed low values of adherence.
\end{abstract}

DESCRIPTORS

Patient Care Bundles; Pneumonia, Ventilator-Associated; Intensive Care Units. 


\section{INTRODUCTION}

Ventilator-Associated Pneumonia (VAP) is a frequent infection in Intensive Care Units (ICUs), ${ }^{1}$ representing $45 \%$ of all nosocomial infections acquired in Europe, and the prevalence of nosocomial pneumonia in ventilated patients may vary from $9 \%$ to $68 \% .^{2-4}$ In the United States, it is estimated that $39 \%$ of pneumonias are associated with mechanical ventilation. ${ }^{5}$ In Brazil, studies show that the prevalence varies from $17.4 \%$ to $48.1 \% .^{2-3,6-7}$

American Thoracic Society and Infectious Diseases Society of America define VAP as the pneumonia that occurs in mechanical ventilation patients for a time equal to or greater than 48 hours, and up to 24 hours after the endotracheal extubation of these patients. ${ }^{8}$

The patients that receive invasive mechanical ventilation are at risk of numerous complications including pneumonia. Some studies attribute the VAP mortality between 20 to $71 \%$, ${ }^{9}$ but this rate is variable and depends on care provided. VAP is considered the main cause of death among nosocomial infections, ${ }^{1}$ exceeding the death rate due to central line catheter infections, severe sepsis, and respiratory tract infections in non-intubated patients. ${ }^{10}$ Maybe the most worrisome aspect of VAP is the high associated mortality rate. ${ }^{10}$

The occurrence of VAP prolongs hospital stay and increases health care costs. ${ }^{1,3,6-7,11}$ Therefore, the VAP diagnosis is important to provide the proper treatment and, consequently, reduce the mortality. ${ }^{1}$

Measures that aim to decrease the incidence of VAP are extremely important and have been increasingly discussed in literature, such as the implementation of so-called VAP prevention Bundles. ${ }^{12}$ The Bundle is a package of simple patient care measures, punctual and in small numbers, which collaborate to control nosocomial infections. When all the Bundle measures are performed together, better results occur than when implemented individually. 4,13

The VAP prevention Bundle was originally elaborated in 2005 by Institute of Healthcare
Improvement during 100,000 Lives Campaign. This institute proposed the adoption of four measures: head of the bed elevated to $30^{\circ}$; daily awakening through protocols for periodic removal of sedation; adequate prophylaxis for gastric ulcer and prevention of deep venous thrombosis. Subsequently, in 2010, the oral hygiene performance with chlorhexidine was included. ${ }^{14}$ Various studies has suggested the inclusion or change in priority of other measures in VAP Bundles, whatever they are, the implementation of a protocol of weaning from mechanical ventilation, the use of silver-coated orotracheal tubes, continuous subglottic aspiration and the maintenance of proper orotracheal tube cuff pressure between 20 and $30 \mathrm{cmH}_{2} \mathrm{O}$, all these measures aim to reduce the occurrence of VAP. ${ }^{15-16}$

Among the most consensual and easiest-toassess measures, it is worth noting the elevation of the head of the bed between 30 and 45 degrees, daily interruption of sedation and daily assessment of readiness to extubate the patient, oral hygiene with chlorhexidine and maintenance of proper orotracheal tube cuff pressure between 20 and $30 \mathrm{cmH}_{2} \mathrm{O}$, low cost measures and that are easily executed by health staff. ${ }^{17-18}$

Considering the morbimortality implications, increase of costs and days of hospitalization, among other damages related to VAP, the following is justified: the importance of adherence on the part of health professionals to measures of infection control and prevention, including the Bundles. In this context, the objective of this study was to assess adherence of health professionals to some of the measures of VAP prevention Bundles in an Adult ICU.

METHOD

It is a retrospective, documentary study performed in the Adult ICU of a high-complexity federal university hospital, located in the city of Uberlândia, Minas Gerais, Brazil. The ICU under study consists of 30 beds for hospitalization of patients aged 14 years and over, with clinical, neurological, surgical and/or traumatic diagnosis. 
The inclusion criteria were: patients hospitalized in ICU in the period from January to June 2014, over 18 years of age, of both sexes, who were receiving mechanical ventilation for more than 48 hours on admission or were receiving mechanical ventilation on admission and remained on it for at least 48 hours in ICU.

The data were collected from patient records, by the researchers themselves. A record for sociodemographic and clinical characterization was made, containing the following patient data: age, sex, admission diagnoses, ICU length of stay, length of hospital stay, time of mechanical ventilation, ICU severity scores - Acute Physiology and Chronic Health Evaluation (APACHE II), Simplified Acute Physiology Score 3 (SAPS 3) and outcome of ICU admission. The admission diagnoses were classified as clinical, neurological, surgical and/or traumatic, observing that the patient could have more than one admission diagnosis. The outcome was classified as discharge from the ICU or death in the ICU.

To assess adherence to selected items from the Bundle (head of the bed elevated to $30^{\circ}$, proper cuff pressure between 20 and $30 \mathrm{cmH}_{2} \mathrm{O}$, oral hygiene performance and oral hygiene performance with chlorhexidine), Bundle checklists completed daily by the Nursing and Physiotherapy staff of Adult ICU were analyzed, as well as notes in medical records were evaluated. For these items, the adherence percentage of each item was calculated (number of days when there was a record of adherence to the Bundle divided by the number of days of hospitalization in which the patient was receiving mechanical ventilation multiplied by 100 , unit \%), for each of the patients separately. The Bundle actions are routine in the unit; as a result, there was no intervention to implement or improve adherence to the Bundle. The assessment of adherence was based on health staff records, and assessment in loco of care and filling out the forms were not performed.

For the comparison of data of quantitative variables between the patients (with and without
VAP), the data from each group were tested for normality by Kolmogorov-Smirnov Lilliefors test, given that in all the cases, at least one group did not show normality. In this sense, the medians were compared by unpaired Wilcoxon test. The association between the presence or absence of VAP and the qualitative variables was verified with the Chi-Square Test of Independence with continuity correction. The significance level was 0.05 for all the analyses.

The data collection was performed after approval of the Research Ethics Committee (CEP) of Federal University of Uberlândia under the CAAE number 43409414800005152, and the guidelines and standards recommended by Resolution number 466 from 2012 of National Health Council of the Ministry of Health of Brazil, which regulates research involving human beings, were followed. ${ }^{19}$ The study was exempted from signing the Informed Consent Form (ICF).

\section{RESULTS}

During the study period, 274 patients were admitted to the Adult ICU, of whom 198 patients (72.26\%) fulfilled the inclusion criteria. Of the sample of patients, 53 had VAP (prevalence of 26.76\%).

The average age was 52.84 years, 52.29 years for the patients with VAP and 53.04 years without VAP. The distribution by sex was $65.13 \%(127 / 195)$ for the male and $34.87 \%(68 / 195)$ for the female, there was no difference between the groups. The main cause of hospitalization in both groups (with and without VAP) was surgical $\left(X^{2}=0.028 ; p=0.867\right)$, followed by clinical $\left(X^{2}=0.160 ; p=0.689\right)$. In many cases, the same patient had more than one diagnosis on admission (Table 1).

APACHE II and SAPS did not differ between the groups with and without VAP $(p=0.485$ and $p=0.498$, respectively). The time of mechanical ventilation until the diagnosis of VAP was on average $8.55 \pm$ standard error of 0.74 days, characterizing late VAP (that develops from the fifth day of mechanical ventilation). The time of mechanical ventilation and ICU length of 
stay were longer in patients with VAP (both with $p<$

0.001 ) (Table 1).

Table 1 - Profile and outcome characteristics of the patients receiving mechanical ventilation in an adult intensive care unit of a university hospital. Uberlândia, Minas Gerais, Brazil, 2014.

\begin{tabular}{|c|c|c|c|}
\hline \multirow{2}{*}{ Variables } & Without VAP & With VAP & Statistics \\
\hline & $n=145$ & $n=53$ & $X^{2}(p)$ \\
\hline \multicolumn{4}{|l|}{ Sex - \% Yes (n) } \\
\hline Male & $61.54(88)$ & $75(39)$ & $2.48(0.115)$ \\
\hline Female & $38.46(55)$ & 25(13) & \\
\hline \multicolumn{4}{|l|}{ Inpatient Diagnosis - \% Yes (n) } \\
\hline Clinical & $40.28(58)$ & $35.85(19)$ & $0.16(0.689)$ \\
\hline Surgical & $52.08(75)$ & $54.72(29)$ & $0.03(0.867)$ \\
\hline Trauma & $16.67(24)$ & $30.19(16)$ & $3.58(0.058)$ \\
\hline Neurological & $18.06(26)$ & $24.53(13)$ & $0.66(0.418)$ \\
\hline \multicolumn{4}{|l|}{ Outcome - \% Yes (n) } \\
\hline ICU discharge & $60.7(88)$ & $50.9(27)$ & $1.21(0.270)$ \\
\hline ICU death & $39.3(57)$ & $49.1(26)$ & \\
\hline Characteristic & \multicolumn{2}{|c|}{ Mean \pm Standard Error (Median) } & $Z(p)$ \\
\hline Age (years) & $53.04 \pm 1.68(56.00)$ & $52.29 \pm 2.61(56.50)$ & $-0.25(0.799)$ \\
\hline APACHE II (points) & $18.36 \pm 0.72(17.00)$ & $19.06 \pm 1.07(18.00)$ & $-0.70(0.485)$ \\
\hline SAPS 3 (points) & $63.52 \pm 1.17(61)$ & $61.13 \pm 2.21(62)$ & $-0.68(0.498)$ \\
\hline ICU length of stay (days) & $18.12 \pm 1.16(15.00)$ & $30.89 \pm 2.80(28.00)$ & $-4.81(<0.001)$ \\
\hline Time of mechanical ventilation (days) & $10.34 \pm 0.72(8.00)$ & $22.36 \pm 1.99(17.00)$ & $-6.74(<0.001)$ \\
\hline
\end{tabular}

VAP: Ventilator-associated pneumonia; APACHE: Acute Physiology and Chronic Health Evaluation; SAPS: Simplified Acute Physiology Score; $X^{2}$ : chi-square statistics; $Z$ : $Z$ statistics of unpaired Wilcoxon test.

With respect to the items assessed referring to adherence to Bundle VAP prevention measures, differences were not verified between the groups of patients who had or did not have VAP in any of the items assessed, whatever they are: head of the bed elevated to $30^{\circ}(p=0.193)$, proper cuff pressure between 20 and $30 \mathrm{cmH}_{2} \mathrm{O}(p=0.142)$, oral hygiene performance with chlorhexidine $(p=0.356)$ and oral hygiene performed ( $p=0.257)$. The Bundle items with lower adherence were oral hygiene performance with chlorhexidine and measure of proper cuff pressure between 20 and $30 \mathrm{cmH}_{2} \mathrm{O}$, respectively, as verified in Table 2.

Table 2 - Adherence to Bundle items to prevent ventilator-associated pneumonia in an adult intensive care unit of a university hospital. Uberlândia, Minas Gerais, Brazil, 2014.

\begin{tabular}{lccc}
\hline \multirow{2}{*}{ VAP Bundle } & \multicolumn{2}{c}{ Mean \pm Standard Error (Median) } & \multicolumn{1}{c}{$Z(p)$} \\
\cline { 2 - 3 } & Without VAP & With VAP & $-1.301(0.193)$ \\
Head of bed at $30^{\circ}$ & $96.08 \pm 0.85(100)$ & $97.00 \pm 0.72(100)$ & $-1.467(0.142)$ \\
Proper cuff pressure & $7.43 \pm 1.24(0.00)$ & $6.45 \pm 1.32(2.04)$ & $-1.135(0.257)$ \\
Oral hygiene & $74.74 \pm 2.42(82.10)$ & $82.18 \pm 2.54(85.71)$ & $-0.923(0.356)$ \\
Oral hygiene with chlorhexidine & $0.26 \pm 0.14(0.00)$ & $0.50 \pm 0.29(0.00)$ & \\
\hline
\end{tabular}

$Z$ : $Z$ statistics of unpaired Wilcoxon test.

\section{DISCUSSION}

One of the great challenges of the millennium, referring to process management, is increase the production with the lowest possible cost and workload optimization, incorporating new technologies in real time. In health, this challenge is also present. However, when we talk about health, especially care associated with hospitalization, this increase in 
production should be linked to the concept of patient safety, without increasing adverse events to users, as the workload has affected the patient safety. ${ }^{20}$

Based on this assumption, the identification of risk factors for adverse events in health is essential for quality improvement of service provided, as well as for the increase in production in health facilities. In this context, nosocomial infections, more especially VAPs, deserve special attention by virtue of their significant incidence and prevalence in patients hospitalized in ICUs, with impacts in morbimortality of the patient. In the present study, we observed an increase in time of mechanical ventilation and in patient's hospital stay, which corroborates other studies that affirms that adverse events, such as nosocomial infections, make a significant impact in the quality of care, leading to an increase in morbimortality rates, prolongation of hospital stay and, consequently, rising hospital costs. ${ }^{3-}$ 4,6-7

It was verified that patients with trauma diagnosis showed higher prevalence of VAP, although not significant. The increase in VAP risk in these patients, especially in those who had severe trauma, is due to the fact that as traumas are emergency situations and intubation is often performed in high stress situations (it is an invasive procedure and that compromises the defense barriers of the lower respiratory tract), there is the risk of non-performance under proper technique, which, consequently, makes the mechanical ventilation a risk factor for the development of pneumonia. ${ }^{11,21}$

Although various studies highlight the importance of adherence of health staff to Bundle to reduce the occurrence of VAP, ${ }^{15-16}$ the present study did not come to the same conclusion when comparing adherence in two groups. Statistically significant difference was not verified in adherence to Bundle between groups of patients with and without VAP. Similar data are also found in another study, which verified an increase in adherence to ventilation Bundle measures, but without reducing the incidence of VAP. ${ }^{22}$ The absence of difference between the two groups may have been due to past factors to ICU admission, differences in risk variables or other covariables.

Another study in the same unit demonstrated that previous procedures performed outside the ICU increased the chances of nosocomial infection in ICU. ${ }^{23}$ This datum reinforces the need to evaluate the time of invasive ventilation of these patients previously to ICU admission and the adherence to Bundle cares in care units where the patients were previously admitted. Moreover, such a fact may also be justified by the failure to fill out medical records, results that countless studies have demonstrated on the low quality of the records in the medical record of care provided, $24-25$ and that can be a limiting factor for documentary and retrospective studies based on the records in patient records. In this sense, it is believed that may be occurred failure in the procedure record of oral hygiene with chlorhexidine since it is reported in the medical record only as oral hygiene and, in many cases, the procedures are recorded without details and description of products used.

In the same population studied, the main risk factors for the development of VAP were time of mechanical ventilation before ICU hospitalization (reinforcing the role of health staff care before ICU admission), the Nursing Activities Score (NAS) in ICU admission, the use of rocuronium bromide, use of propofol and presence of tracheostomy. On the other hand, the protective factors were the increase in percentage of adequacy of workload and the increase in NAS increment in hospitalization. ${ }^{11}$ Furthermore, the Bundle item oral hygiene, that is, the increase of adherence was not confirmed as a protective factor for VAP in these patients, not suffering the effect of other covariables. ${ }^{11}$

The main limitation of this study was the assessment of adherence to Bundle from data from patient records or from institutional forms, as such a fact does not allow the data validation, which can cause confounding. The assessment in loco would be 
necessary, in addition to audits that would improve the records of care provided to patients in health services.

Unfortunately, there were no statistical data available on the current situation of the institution concerning adherence to Bundles since it was not reevaluated. Nevertheless, we observed that, after performing this study, actions were taken, such as the implementation of Bundles from adherence of institution in national programs to prevent health care-associated infections, in SUS Institutional Development Support Program (PROADI-SUS) of Brazilian Ministry of Health. In this way, new studies are still necessary to verify the improvement of adherence to Bundle, which certainly focus on reducing occurrence of VAP.

The results of the present study will be able to subsidize the implementation of educational measures to increase adherence of health professionals to VAP prevention measures, which will reverberate in the improvement of patient care, reduction of infection and mortality rates, length of stay and health care costs. Among the strategies that can be adopted to improve adherence to Bundles, we cite the increase in the provision of in-service education, assessment of adherence to Bundle measures in real time with disclosure of results, and the introduction of alert mechanisms for non-adherence.

\section{CONCLUSION}

The present study allowed us to conclude that adherence to some Bundle VAP prevention measures (head of the bed elevated to $30^{\circ}$, oral hygiene, oral hygiene with chlorhexidine and proper cuff pressure) was not different between patients with or without VAP and showed low values of adherence based on the records in medical record.

Therefore, there is a need to improve the making and detailing of records of care provided by health professionals in intensive care units on Bundle VAP prevention measures, as with these initiatives we will be able to obtain more reliable retrospective results.

\section{RESUMO}

Introdução: A Pneumonia Associada à Ventilação Mecânica (PAV) é uma infecção frequente em pacientes internados em unidades de terapia intensiva. A ocorrência de PAV prolonga o tempo de internação hospitalar e aumenta os custos da assistência. 0 objetivo deste estudo é avaliar a adesão de profissionais de saúde a um pacote de intervenções (Bundle) de prevenção de PAV. Delineamento: Estudo retrospectivo, documental realizado em uma unidade de terapia intensiva de um hospital universitário. A amostra foi composta por pacientes internados no período de janeiro a junho de 2014, que preencheram os critérios de inclusão. A coleta de dados foi realizada por meio de consulta a prontuários. Resultados: Foram verificados aumento do tempo de internação dos pacientes com PAV e baixa adesão aos itens do Bundle. A pressão adequada do cuff e a higiene oral com o antisséptico padronizado foram os itens com menor adesão. Implicações: A adesão a algumas das medidas do Bundle para a prevenção de PAV não foi diferente entre os grupos de pacientes (com ou sem PAV) e apresentou baixos valores de adesão.

\section{DESCRITORES}

Pacotes de Assistência ao Paciente; Pneumonia Associada à Ventilação Mecânica; Unidades de Terapia Intensiva.

\section{RESUMEN}

Introducción: La neumonía asociada a ventilación mecánica (NAVM) es una infección frecuente en pacientes ingresados en unidades de cuidados intensivos. La aparición de NAVM prolonga la estadía en el hospital y aumenta los costos de asistencia. El objetivo de este estudio es evaluar la adherencia de los profesionales de la salud a un conjunto de intervenciones (Bundle) de prevención de NAVM. Delineación: Estudio documental retrospectivo realizado en una unidad de cuidados intensivos de un hospital universitario. La muestra consistió en pacientes hospitalizados de enero a junio de 2014, que cumplieron con los criterios de inclusión. La recolección de datos se realizó consultando los registros médicos. Resultados: Hubo un aumento en la duración de la estancia hospitalaria de los pacientes con NAVM y una baja adherencia a los elementos del Bundle. La presión adecuada del manguito y la higiene bucal con antiséptico estandarizado fueron los ítems con menor adherencia. Implicaciones: La adhesión a algunas de las medidas del Bundle para la prevención de NAVM no fue diferente entre los grupos de pacientes (con o sin NAVM) y mostró valores de adherencia bajos.

\section{DESCRIPTORES}

Paquetes de Atención al Paciente; Neumonía Asociada al Ventilador; Unidades de Cuidados Intensivos. 


\section{REFERENCES}

1. Chen CY, Lin WC, Yang HY. Diagnosis of ventilator-associated pneumonia using electronic nose sensor array signals: solutions to improve the application of machine learning in respiratory research. Respir Res [Internet]. 2020 Jan [cited 2020 Jan 10]; 21:45-56. Available from: https://doi.org/10.1186/s12931-020-1285-6

2. Camargo LFA, De Marco FV, Barbas CSV, Hoelz C, Bueno MAS, Rodrigues Jr. M, et al. Ventilator associated pneumonia: comparison between quantitative and qualitative cultures of tracheal aspirates. Crit Care [Internet]. 2004 Oct [cited 2019 Jun 10]; 8:422-430. Available from: https://doi.org/10.1186/cc2965

3. Rocha LA, Vilela CAP, Cezário RC, Almeida AB, Gontijo Filho P. Ventilator-associated pneumonia in an adult clinical-surgical intensive care unit of Brazilian university hospital: incidence, risk factors, etiology, and antibiotic resistance. Braz J Infect Dis [Internet]. $2008 \mathrm{Jan}$ [cited 2019 Jun 10]; 12(1):80-85. Available from: http://dx.doi.org/10.1590/S1413-86702008000100017

4. Mota ÉC, Oliveira SP, Silveira BRM, Silva PLN, Oliveira AC. Incidência da pneumonia associada à ventilação mecânica em unidade de terapia intensiva. Medicina [Internet]. 2017 Feb [cited 2019 Jun 10]; 50(1):39-46. Available from: http://dx.doi.org/10.11606/issn.2176-7262.v50i1p39-46

5. Magill SS, Edwards JR, Bamberg W, Beldavs ZG, Dumyati G, Kainer M, et al. Multistate Point-Prevalence Survey of Health CareAssociated Infections, 2011. N Engl J Med [Internet]. 2014 Mar [cited 2019 Jun 10]; 370(13):1198-1208. Available from: https://doi.org/10.1056/NEJMoa1306801

6. Rello J, Allegri C, Rodriguez A, Vidaur L, Sirgo G, Gomez F, et al. Risk factors for Ventilator-associated Pneumonia by Pseudomonas aeruginosa in Presence of Recent Antibiotic Exposure. Anesthesiology [Internet]. 2006 Oct [cited 2019 Jun 10]; 105(4):709-14. Available from: https://www.ncbi.nlm.nih.gov/pubmed/17006069

7. Rodrigues PMA, Carmo Neto E, Santos LRC, Knibel MF. Pneumonia associada à ventilação mecânica: epidemiológica e impacto na evolução clínica de pacientes em uma unidade de terapia intensiva. J Bras Pneumol [Internet]. 2009 Nov [cited 2019 Jun 10]; 35(11):1084-1091. Available from: http://dx.doi.org/10.1590/S1806-37132009001100005

8. American Thoracic Society; Infectious Diseases Society of America. Guidelines for the management of adults with hospital-acquired, ventilator-associated, and healthcare-associated pneumonia. Am J Respir Crit Care Med [Internet]. 2005 Feb [cited 2019 Jun 10]; 171(4):388-416. Available from: https://doi.org/10.1164/rccm.200405-644ST

9. Kalanuria AA, Zai W, Mirski M. Ventilator-associated pneumonia in the ICU. Crit Care [Internet]. 2014 Mar [cited 2019 Jun 10]; 18(2):208. Available from: https://www.ncbi.nlm.nih.gov/pmc/articles/PMC4056625/

10. Institute for Healthcare Improvement. How-to Guide: Prevent Ventilator-Associated Pneumonia. Cambridge, MA: Institute for Healthcare Improvement; 2012. Available from: http://www.ihi.org/resources/Pages/Tools/HowtoGuidePreventVAP.aspx

11. Gomes F A, Roder DVDB, Mendonca GS, Felice RO, Cunha TM, Mendes-Rodrigues C. The nursing workload assessed through the Nursing Activities Score as a predictor for the occurrence of ventilator-associated pneumonia in an adult intensive care unit. $\mathrm{J}$ Nurs

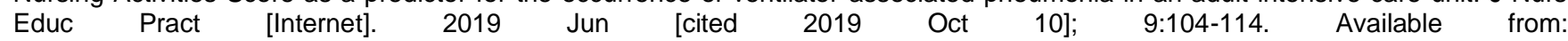
http://www.sciedu.ca/journal/index.php/jnep/article/view/14956

12. Gunasekera P, Gratrix A. Ventilator-associated pneumonia. BJA Education [Internet]. 2016 Jan [cited 2019 Jun 10]; 16(6):198-202. Available from: https://doi.org/10.1093/bjaed/mkv046

13. Lachman P, Yuen S. Using care Bundles to prevent infection in neonatal and paediatric ICUs. Curr Opin Infect Dis [Internet]. 2009 Jun [cited 2019 Jun 10]; 22(3):224-228. Available from: https://www.ncbi.nlm.nih.gov/pubmed/19369867

14. Halpern NA, Hale KE, Sepkowitz KA, Pastores SM. A world without ventilator-associated pneumonia: Time to abanon surveillance and deconstruct the Bundle. Crit Care Med [Internet]. 2012 Jan [cited 2019 Jun 10]; 40(1):267-70. Available from: https://www.ncbi.nlm.nih.gov/pubmed/22179342

15. Wip C, Napolitano L. Bundles to prevent ventilator-associated pneumonia: how valuable are they? Curr Opin Infect Dis [Internet]. 2009 Abr [cited 2019 Jun 10]; 22:159-166. Available from: https://www.ncbi.nlm.nih.gov/pubmed/19276975

16. Ramirez P, Bassi Gl, Torres A. Measures to prevent nosocomial during mechanical ventilation. Curr Opin Crit Care [Internet]. 2012 Feb [cited 2019 Jun 10]; 18(1):86-92. Available from: https://www.ncbi.nlm.nih.gov/pubmed/22186217

17. Rello J, Afonso E, Lisboa T, Ricart M, Balsera B, Rovira A, et al. A care bundle approach for prevention of ventilator-associated pneumonia. Clin Microbiol Infect [Internet]. 2013 Apr [cited 2019 Jun 10]; 19: 363-369. Available from: https://www.ncbi.nlm.nih.gov/pubmed/22439889

18. Nseir S, Lorente L, Ferrer M, Rouzé A, Gonzalez O, Li Bassi G, et al. Continuous control of tracheal cuff pressure for VAP prevention: a collaborative meta-analysis of individual participant data. Ann Intensive Care [Internet]. 2015 Dec [cited 2019 Jun 10]; 5:43. Available from: https://www.ncbi.nlm.nih.gov/pubmed/26603289/ 
19. Brasil. Ministério da Saúde. Conselho Nacional de Saúde. Resolução n. 466, de 12 de dezembro de 2012. Dispõe sobre as diretrizes e normas regulamentadoras de pesquisas envolvendo seres humanos. Brasília: MS; 2012. Available from: http://conselho.saude.gov.br/resolucoes/2012/Reso466.pdf

20. Fagerström L, Kinnunen M, Saarela J. Nursing workload, patient safety incidents and mortality: an observational study from Finland. BMJ Open [Internet]. 2018 Jul [cited 2019 Jun 10]; 8:e016367. Available from: http://dx.doi.org/10.1136/bmjopen-2017-016367

21. Wałaszek M, Kosiarska A, Gniadek A, Kołpa M, Wolak Z, Dobroś W, et al. The risk factors for hospital-acquired pneumonia in the Intensive Care Unit. Przegl Epidemiol [Internet]. 2016 Aug [cited 2019 Jun 10]; 70(1):15-20,107-10. Available from: https://www.ncbi.nlm.nih.gov/pubmed/27344468

22. Sachetti A, Rech V, Dias AS, Fontana C, Barbosa GL, Schlichting D. Adesão às medidas de um Bundle para prevenção de pneumonia associada à ventilação mecânica. Rev Bras Ter Intensiva [Internet]. 2014 Jan [cited 2019 Jun 10]; 26(4):355-359. Available from: http://dx.doi.org/10.5935/0103-507X.20140054

23. Silva RF, Mendes-Rodrigues C, Pereira EBS, Röder DVDB, Gomes FA. Risk factors for bloodstream infection and influence on mortality rate. Rev Pre Infec e Saúde [Internet]. 2017 Jan [cited 2019 Jun 10]; 3(3):23-28. Available from: http://www.ojs.ufpi.br/index.php/nupcis/article/view/6476

24. Antunes AV, Lourenço AM, França CE, Mendes-Rodrigues C. Evaluation of nursing notes before and after a training activity in a university hospital. Rev Pre Infec e Saúde [Internet]. 2018 Aug [cited 2019 Jun 10]; 4:7208-7220. Available from: https://doi.org/10.26694/repis.v4i0.7208

25. Souza RC, Jesus NM, Antunes AV, Mendes-Rodrigues C. Relationship beetween Knowledge and Suitability of Nursing Notes: a disconnect between knowledge and practice. Rev Pre Infec e Saúde [Internet]. 2019 Jan [cited 2019 Jun 10]; 5:8274. Available from: https://doi.org/10.26694/repis.v5i0.8274

\section{COLLABORATIONS}

FAG: substantial contributions in work conception, in data collecting, analysis and interpretation; in writing the article and in its critical review; and in the final version to be published. DVDBR, TMC, GMCF and CMR: substantial contributions in data collecting, analysis and interpretation. GSM: substantial contributions in writing the article and in its critical review. EBSP: substantial contributions in writing the article and in its critical review; and in the final version to be published. All the authors agree and take responsibility for the content of this manuscript version to be published.

\section{ACKNOWLEDGMENTS}

Does not apply.

\section{AVAILABILITY OF DATA}

Does not apply.

\section{FUDING SOURCE}

Does not apply.

\section{CONFLICTS OF INTEREST}

There are no conflicts of interest to declare. 